\title{
ASSESSMENT OF SITUATION IN CASE OF SHIPS IMPACT TO SEA BED
}

\section{OCENA SYTUACJI PODCZAS UDERZENIA STATKU W DNO}

\author{
Wiesław Galor \\ Maritime University of Szczecin, Faculty of Navigation \\ Wały Chrobrego 1/2, 70-500 Szczecin, Poland \\ E-mail: (1)w.galor@am.szczecin.pl
}

\begin{abstract}
The under-keel clearance (UKC) of a ship in the port water area should be such that a ship moves safely. In some specific conditions it happen the ship impact the sea bottom. The undesired strike against the ground can damage the ship hull, but in many cases it has not happened. It depends on relation between of ships movement parameters and ground feature. The paper presents the assessment of damage possibility of ship's hull and algorithm of calculation of ships movement parameters during contact with sea bed.
\end{abstract}

Keywords: safety of navigation, under keel clearance, ships impact to sea bed, damage of ship's hull

Streszczenie. Zapas wody pod stępką statku (ZWPS) powinien zapewnić bezpieczny ruch statku po akwenach portowych. W niekorzystnych warunkach może wystapić uderzenie statku $\mathrm{w}$ dno akwenu. Uderzenie statku $\mathrm{w}$ grunt może spowodować uszkodzenie kadłuba, choć

w wielu przypadkach to nie występuje. Zależy to od relacji pomiędzy parametrami ruchu statku

i własnościami gruntu. W artykule przedstawiono ocenę możliwości uszkodzenia kadłuba statku oraz algorytm obliczania parametrów ruchu podczas kontaktu z dnem akwenu.

Słowa kluczowe: bezpieczeństwo nawigacji, zapas wody pod stępką, uderzenie statku w dno akwenu, uszkodzenie kadłuba statku 


\section{Introduction}

The situation when a ship's hull impacts the sea bed do often results in serious damage. The damage may be of various kinds:

- tearing of bottom plating,

- crushing of deck,

- folding of web frames,

- stretching of shell plating.

That is why the evaluation of ship's movement safety should allow for its impact against the bottom, on condition that the risk of the impact ( $\left.\mathrm{R}_{\mathrm{adm}}\right)$ does not exceed the accepted level (hull damage) [3]. That incident can be described as follows:

$$
R_{a d m}=P\left[Z_{c} \leq U K C\right] \quad \text { for } \mathrm{C} \leq \mathrm{c}_{\min }
$$

where:

$Z_{c} \quad$ - the list distance between ship's hull and bottom during manoeuvring,

C - losses,

$c_{\min }-$ acceptable level of losses.

Maritime administration responsible for the safety of navigation wants the UKC to be relatively high. This, in turn, reduces the possible use of ships' capacity to the full, which for both ship owners and charterers is far from advantageous. The determination of permanent value of UKC was connected with decade-long observations and restrictions in sufficiently accurate determination of its components [5]. However, advances in the field, i.e. scientific methods enable the optimization of the UKC value. The objective function can be written as:

$$
U K C=R_{\min } \rightarrow \min
$$

with the restrictions

where:

$$
R \leq R_{a d}
$$

$R \quad$ - risk of manoeuvring in an area,

$R_{a d} \quad$ - admissible navigational risk defined as an acceptable loss level. 
The level of losses sustained from the impact against the ground depends on many factors, the most important of which is the type of bottom (ground). The losses arising from the fact that a ship hits the ground while moving, such as hull damage or, possibly, loss of cargo (particularly liquid cargo, which may pollute the marine environment) depend on a number of factors which can be expressed by a variety of measures. The kind and degree of hull damage depends mainly on the energy absorbed by the hull when hitting the bottom. The one of these is maximum ship hull load less than admissible value caused damage of its. The maximum ship hull load when hitting the ground can be defined as dependent on the probability as:

$$
P_{c}=P\left(Q_{s g r}>Z_{G}\right)
$$

where:

$Q_{s g r} \quad$ - admissible pressure on ship's hull

$Z_{G} \quad$ - passive ground pressure.

\section{The ship's parameters during sea bed striking}

The risk of accident arise in situation when under keel clearance is insufficient, what depend on many factors [4]. Furthermore, the type of accident is taken into account different than generally descript in literature as grounding or striking the edge of coast. It regards of ships impact the bottom of ground with fixed vertical ordinate. Considering, the types of ship moving impacts into the bottom can classify in according of following way:

- even keel,

- trim to the stern (Figure 1),

- trim to the bow (Figure 2).

During a ship's striking the bottom of an area built of sandy or argillaceous ground, for a vessel in progressive movement, there occurs a gradual sinking of the hull into the ground (until the ship stops). The mechanism of the ship's striking the area's bottom depends on the ship's draft, namely whether the vessel is trimmed by the bows, the stern or if it is loaded on an even keel. During a ship's striking the bottom of an area of fragmented ground, for a vessel in progressive movement, there occurs gradual sinking of the hull into the ground (until the vessel's stoppage). During this process 
there can be distinguished the plough-in phase bound with longitudinal motion and the penetration (sinking) in a vertical direction [3].

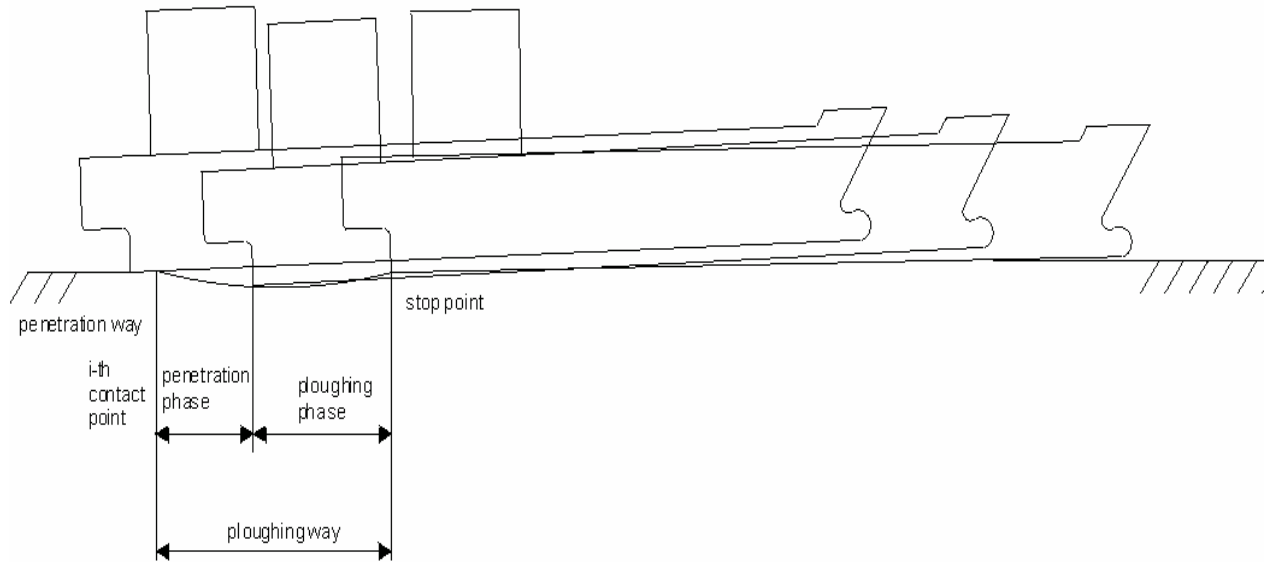

Figure1. The ships strike with stern trim

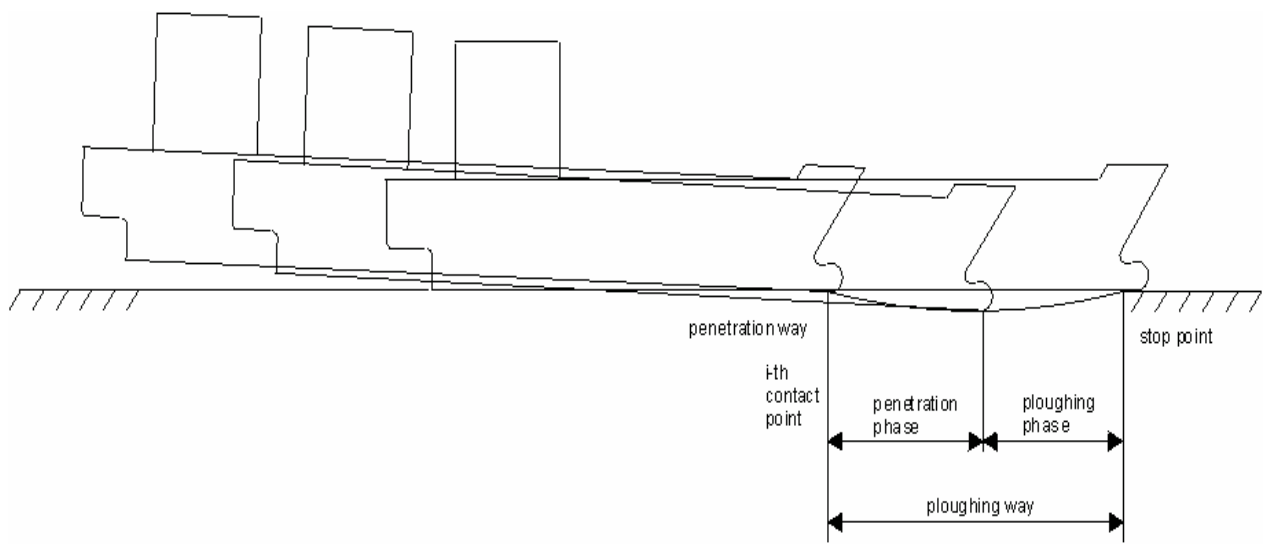

Figure 2. The ships strike with bow trim

There has been prepared an algorithm of calculating vessel movement parameters when striking the port water area ground [3]. It has been applied in a computer simulation model of the vessel's movement in the area. This permits risk determination of the vessel striking the area bottom and its results (likelihood of hull damage). The stopping of ship will be fulfill when 
the initial kinetic energy (in moment of first contact with sea-bed) became completely lost, i.e. will be change to following components:

$$
m V_{H o}^{2} / 2=\int P_{R T} d l+\int P_{B} d l+\int P_{R K} d l
$$

where:

$m \quad$ - ships mass and water added mass (virtual ships mass),

$V_{H o} \quad-\quad$ horizontal component of ships velocity in moment of contact with sea-bed,

$\int P_{R T} d l \quad$ - work performed for overcoming friction force of the hull's bottom part,

$\int P_{B} d l \quad-\quad$ work performed for overcoming the resistance of friction of the lateral parts of the hull,

$\int P_{R K} d l \quad$ - work performed for overcoming soil wedge.

The ships velocity during contact with ground of sea-bed will be by and by decrease until stopping. The way of ship's stopping will be equal:

where:

$$
L_{K}=\int V_{H i} d t \quad d l a t \in\left(t_{0} \div t_{K}\right)
$$

$L_{K} \quad$ - way of ship's stopping,

$t_{K} \quad$ - $\quad$ time to ship's stopping,

$V_{H i} \quad$ - horizontal component of ship's velocity during phase of ploughing.

$$
V_{H i}=\left(2 \cdot \Delta E_{K i} / m\right)^{1 / 2}
$$

where:

$\Delta E_{K i}$ - decreasing of ship's kinetic energy due to alter on work performed for hull resistances during ploughing.

The friction force of the hull's bottom part is equal of hull friction force $\mathrm{P}_{\mathrm{RT}}$ during penetration into the ground:

$$
P_{R T}=\mu \cdot N
$$

where:

$\mu \quad$ - coefficient of ship's hull friction on ground,

$N$ - ground reaction force on ship's bottom during penetration. 
The friction force of the lateral parts of the hull $\mathrm{P}_{\mathrm{KB}}$ :

$$
P_{K B}=2 \cdot F_{o d p b}\left(L_{S} / Z_{\dot{s}}\right) \operatorname{tg} E \cdot \Delta L_{i}
$$

where:

$F_{\text {odpb }}$ - ground reaction force on lateral part of hull,

$L_{S} \quad$ - line length of hull contact with ground,

$Z_{s r} \quad$ - average depth of ship's penetration into the ground,

$E \quad$ - the friction angle on hull wall

$\Delta L_{i} \quad$ - considered the ship's stopping ways segment.

The passive ground reaction connection with overcoming soil wedge $\mathrm{E}_{\mathrm{RK}}$ (Figure 4):

$$
E_{R K}=f\left(Z, B_{s}, L_{p p}, \beta\right)
$$

where:

$Z \quad$ - depth of ship's penetration into the ground,

$B_{s} \quad$ - width of part of ship into the ground,

$L_{p p} \quad$ - ship's length between perpendicular,

$\beta \quad$ - angle of ship's trim.

Due to ship's penetration of sea bed, the dislocation of some mass of ground (soil wedge) is made. It shifting (forward and aside) caused necessity of making some work performed for overcoming soil wedge by ship's moving bulk.

$$
P_{R K}=W_{E} \cdot \Delta L
$$

where:

$P_{R K} \quad$ - work performed for overcoming soil wedge,

$W_{E} \quad$ - weight of shifted ground,

$\Delta L \quad$ - considered distance of ship moving.

where:

$$
W_{E}=Q_{g} \cdot \gamma_{g}
$$

$Q_{g} \quad-\quad$ capacity of shifted ground,

$\gamma_{g} \quad-\quad$ weight of ground.

The capacity of shifted ground is equal to capacity of bulk penetrating the sea bed (Fig. 3). 

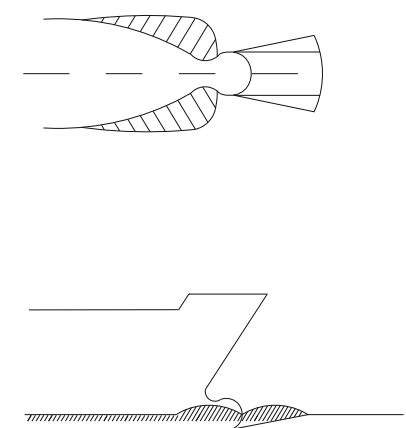

Fig. 3. The passive earth pressure wedge

The pressure of the ship on ground:

$$
\sigma=\frac{N}{S}
$$

where:

$N \quad$ - the push force of ship's hull

$s \quad$ - area of hull contact with ground.

The ship's push on the ground is an effect of decreasing of ship's draft. The greater emergence bear witness about greater pushing. The magnitude of push force will be altering depending on ship's draft and trim. The pushing for even keel will be equal:

$$
\sigma_{i}=\frac{\Delta T_{i} \cdot L p_{p} \cdot B \cdot \delta}{S} \cdot \gamma
$$

where:

$\Delta T_{i} \quad$ - currently draft decreasing,

$L_{p p} \quad$ - length between perpendiculars,

$B \quad$ - breadth of ship,

$\delta \quad$ - ship's block coefficient,

$\gamma \quad$ - water weight specific gravity,

$S \quad$ - surface area of hull contact with ground. 


\section{Algorithm of calculation of ship strike into sea-bed}

In successive steps ship movement parameters during contact with the ground are calculated, which permits the determination of its results. The following steps are accomplished by calculating of:

- initial kinetic energy.

- pressure of the vessel on the area bottom, to decrease the water level or the vessel's draft.

- checking whether passive earth pressure (the ground's reaction) does not exceed the permissible value.

- friction force of the bottom part of the vessel's hull against the ground, taking into account the friction coefficient.

- depth of the vessel's penetration into the ground.

- work performed for overcoming friction force of the hull's bottom part.

- work performed for overcoming the resistance of friction of the lateral parts of the hull for a specified depth of the vessel's penetration into the ground.

- work performed for overcoming soil wedge.

- decrease of the vessel's kinetic energy caused by contact with the ground.

- decrease of the vessel's speed components.

The example of calculation used algorithm is presented below. The basic dates are touched the maximal ship entering the Swinoujscie Port (called SWINOUJSCIE MAX):

- length between perpendiculars

- breadth of ship

$$
\begin{aligned}
\mathrm{L}_{\mathrm{pp}} & =275.0 \mathrm{~m} \\
\mathrm{~B} & =41.0 \mathrm{~m} \\
\mathrm{~T} & =12.8 \mathrm{~m} \\
\delta & =0.8 \\
\mathrm{~V}_{\mathrm{H}} & =5.0 \mathrm{~m} / \mathrm{s}
\end{aligned}
$$

- ship's block coefficient

- initial horizontal component of ship's speed

- initial vertical component of ship's speed

$\mathrm{V}_{\mathrm{V}}=0.01 \mathrm{~m} / \mathrm{s}$

I. The results of calculations are following:

- initial ship's kinetic energy $\mathrm{E}_{\mathrm{K}}=188.250[\mathrm{kNm}]$. 
II. In first step of calculation for period of time equal $10 \mathrm{sec}$ :

- work performed for overcoming friction forces of the hull's - $\mathrm{P}=$ $38.500[\mathrm{kNm}]$,

- decreasing of ship's speed in first step of calculation up to $\mathrm{V}_{\mathrm{H}}=4.95$ $\mathrm{m} / \mathrm{s}$.

III. In next steps of calculations the decreasing of ship's speed up to zero will be stayed:

- over $220 \mathrm{sec}$ from first contact of ship with sea-bed,

- the length of ship's stopping distance $\mathrm{I}_{\mathrm{p}}=273.0 \mathrm{~m}$.

IV. There wasn't overdoing the admissible pressure on ship's hull in this case.

\section{Conclusions}

The UKC should warrant the safe manoeuvring of a ship in the port water area. If keel clearance is great then the safety of ship, then it can cause limiting the quantities of cargo loaded and unloaded, which means lower earnings for the port and stevedoring companies.

A ship can touch the bottom of a port water area due to the reduction of its keel clearance. Such event no has to necessaribily results of damage of ship's hull. The kind and degree of hull damage mainly depend on the energy absorbed by the hull during its impact against the sea bottom.

There is possible to determine of results of ship impact in sea bed. It permits to assess of navigational risk and thus to improve the safety of ship movement in shallow water.

The method presented in this paper permits to asses of safety of navigation during ships impact to sea bed.

\section{References}

1. Galor W., 2002. The safety of navigation on water areas limited by port structures. Szczecin: Edit by FR WSM (in Polish), Szczecin, 2002, (in Polish).

2. Galor W., (2009), Determination of dynamic of under keel clearance of manoeuvring ship, Journal of KONBiN 5 (8), 2008. 
3. Galor W., (2009), Safety of navigation during ships impact to sea bed, Proc. Of XIII Int. Scientific and Technical conf. on Marine Traffic Engineering, Malmo 2009.

4. Gucma S., Marine traffic engineering, Edited by Okrętownictwo i Żegluga, Gdańsk, 2001, (in Polish)..

5. Mazurkiewicz B., 2006. Marine structures. A guide to design Edited by ARCELOR, Gdańsk, 2006, (in Polish).

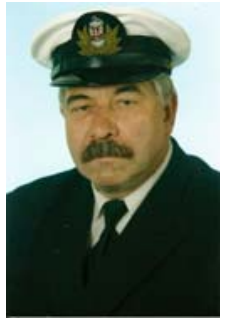

Prof. DSc. Eng. Deck Off. GALOR Wiesław, Professor at Institute of Marine Traffic Engineering, Faculty of Navigation, Maritime University of Szczecin, Poland. Specialization: safety of navigation, marine traffic engineering, safety of ship manoeuvring in limited water area, designing of fender systems. Membership in many scientific committees of conferences and congresses. Many publications in field. 